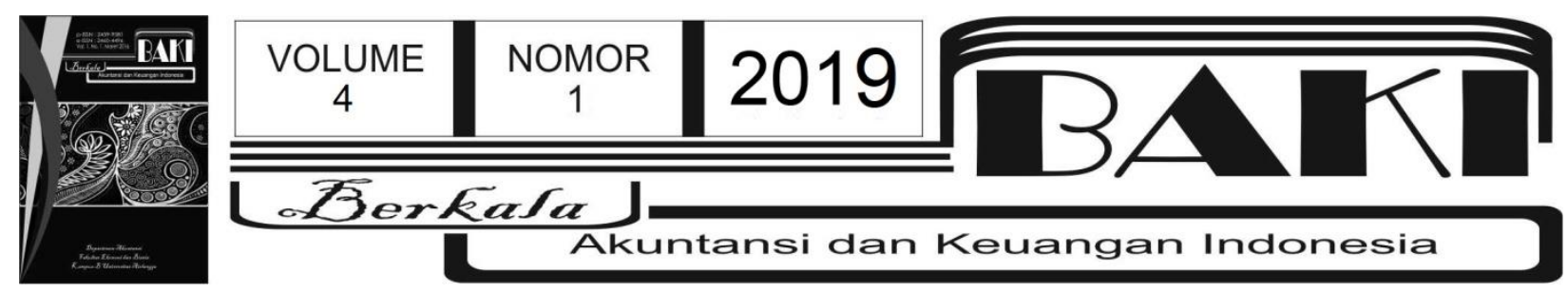

\title{
Faktor yang Mempengaruhi Audit Delay pada Industri Dasar dan Kimia
}

\author{
Isieny Wendy ${ }^{1}$ \\ Vonni Rizal ${ }^{1}$ \\ Hantono ${ }^{1,2}$ \\ ${ }^{1}$ Universitas Prima Indonesia \\ ²hantono 78@yahoo.com
}

\section{INFO ARTIKEL}

Histori Artikel:

Tanggal Masuk 3 Februari 2019

Tanggal Diterima 30 Mei 2019

Tersedia Online 14 Juni 2019

\section{Kata Kunci:}

Audit Delay Kantor Akuntan

Publik; Kompleksitas

Operasional Perusahaan; Total

Aset.

\begin{abstract}
A B STRAK
Penelitian ini bertujuan untuk menguji dan menganalisis pengaruh kantor akuntan publik, kompleksitas operasi perusahaan, dan total aset terhadap audit delay pada industri dasar dan kimia yang terdaftar di Bursa Efek periode 2012-2016. Metode pendekatan kuantitatif dengan jenis penelitian deskriptif kuantitatif digunakan pada penelitian ini. Sampel penelitian adalah sebanyak 22 laporan keuangan. Metode analisis data dalam penelitian ini adalah analisis regresi logistik. Hasil penelitian ini menunjukkan secara simultan akun perusahaan publik, kompleksitas operasi perusahaan, dan total aset tidak berpengaruh signifikan terhadap audit delay pada industri dasar dan kimia yang terdaftar di Bursa Efek periode 2012-2016. Secara parsial, kantor akuntan publik, kompleksitas operasi perusahaan, dan total aset tidak berpengaruh terhadap audit delay pada perusahaan pertambangan yang terdaftar di BEI periode 2011-2015 dengan nilai signifikan $<0,05$. Hasil nilai Nagelkerke $R$ Square dalam penelitian ini adalah 0,31 yang dapat dinyatakan bahwa variabilitas variabel dependen (audit delay) yang dapat dijelaskan oleh variabilitas variabel independen adalah sebesar $31 \%$.
\end{abstract}

\section{Pendahuluan}

Setiap perusahaan go public diwajibkan untuk menyampaikan laporan keuangan yang disusun sesuai dengan Standar Akuntansi Keuangan yang telah diaudit oleh akuntan publik yang terdaftar di Badan Pengawas Pasar Modal (Bapepam). Sebagimana yang dinyatakan 
dalam Pernyataan Standar Akuntansi Keuangan (PSAK: 2009), tentang Kerangka Dasar Penyusunan dan Penyajian Laporan Keuangan, bahwa laporan keuangan harus memenuhi empat karakteristik kualitas yang membuat informasi laporan keuangan bermanfaat bagi sejumlah besar penggunanya. Keempat karakteristik tersebut antara lain dapat dipahami, relevan, keandalan dan dapat dibandingkan.

Karakteristik informasi yang relevan harus mempunyai nilai predikif dan tepat waktu. Setiap perusahaan yang mengeluarkan laporan keuangan pada periode tertentu selalu dinantikan oleh berbagai pihak. Laporan keuangan yang dipublikasikan oleh perusahaan go public tersebut waktu pelaporannya tidak boleh melebihi dari ketentuan yang dikeluarkan oleh BAPEPAM yaitu 90 hari atau pada akhir bulan ketiga setelah penutupan tahun buku. Hal ini sesuai dengan keputusan BAPEPAM No. 36/PM/2003 tentang kewajiban laporan berkala yang menyatakan bahwa laporan keuangan tahunan disertai dengan laporan akuntan dengan pendapat yang lazim harus disampaikan kepada Bapepam selambat-lambatnya pada akhir bulan ketiga (90 hari) setelah tanggal laporan keuangan. Sebelumnya ketepatan waktu penyampaian laporan keuangan telah diatur dalam pasar modal yaitu dalam Undang-undang Nomor 8 Tahun 1995 tentang "Peraturan Pasar Modal" menyatakan bahwa semua perusahaan yang terdaftar dalam pasar modal wajib menyampaikan laporan keuangan secara berkala kepada Bapepam dan mengumumkan kepada masyarakat. Apabila perusahaan-perusahaan tersebut terlambat menyampaikan laporan sesuai dengan dengan ketentuan yang telah ditetapkan oleh Bapepam, maka dikenakan sanksi administrasi sesuai dengan ketentuan yang telah ditetapkan dalam undang-undang. Peraturan mengenai penyampaian laporan keuangan ini telah diperbaharui oleh Bapepam pada tahun 1996, lampiran keputusan Ketua Bapepam Nomor: Kep-80/PM/1996 dan mulai berlaku pada tanggal 17 Januari 1996. Dalam pertauran baru ini disebutkan bahwa perusahaan wajib menyampaikan laporan keuangan tahunan yang telah diaudit selambat-lambatnya 120 hari terhitung sejak tanggal tutup buku perusahaan. Dengan demikian penelitian ini ingin menguji bagaimana pengaruh dari kantor akuntan publik, kompleksitas operasi perusahaan, dan total aset perusahaan terhadap audit delay pada industri dasar dan kimia yang terdaftar di BEI periode 2012 dan 2016.

\section{Tinjauan Pustaka}

\subsection{Kantor Akuntan Publik}

Kantor Akuntan Publik (KAP) adalah suatu bentuk organisasi akuntan publik yang memperoleh izin sesuai dengan peraturan perundang-undangan, yang berusaha di bidang pemberian jasa professional dan dalam praktek akuntan publik. Pengukuran KAP dibagi menjadi dua, yaitu KAP the big four dan KAP non big four. Hal ini juga menunjukkan kualitas 
KAP tersebut. Kualitas KAP dikatakan dapat berpengaruh siginifikan terhadap audit delay, karena sebagian besar perusahaan sudah menggunakan jasa audit KAP the big four yang dapa melakukan auditnya dengan cepat dan efisien (Rachmawati, 2008: 3).

Keempat Kantor Akuntan Publik terbesar di Amerika Serikat disebut Kantor Akuntan Publik internasional "Empat Besar". Keempat kantor ini memiliki cabang di seluruh Amerika Serikat dan seluruh dunia. Kantor Empat Besar mengaudit hampir semua perusahaan besar dan perusahaan kecil baik di Amerika Serikat maupun dunia. Kantor Empat Besar tersebut adalah:

1. KAP Purwantono, Sarwoko, Sandjaja berafiliasi dengan Ernst \& Young.

2. KAP Osman Bing Satrio dan Rekan berafiliasi dengan Deloitte Touche Tohmatsu.

3. KAP Siddharta dan Widjaja berafiliasi dengan Klynveld Peat Marwick Goerdeler (KPMG),

4. KAP Tanudireja Wibisana \& Rekan berafiliasi dengan Price water house Coopers.

\subsection{Kompleksitas Operasional Perusahaan}

Kompleksitas organisasi atau operasi merupakan akibat dari pembentukan departemen dan pembagian pekerjaan yang memiliki fokus terhadap jumlah unit yang berbeda. Ketergantungan yang semakin kompleks terjadi apabila organisasi dengan berbagai jenis atau jumlah pekerjaan dan unit menimbulkan masalah organisasi yang lebih rumit (Ariyani dan Budhiarti 2014). Kompleksitas operasi perusahaan dicerminkan melalui jumlah anak perusahaan atau entitas anak yang dimiliki oleh perusahaan induk dengan kepemilikian saham lebih dari $50 \%$. Anak perusahaan adalah perusahaan yang dikontrol oleh perusahaan lain, yaitu induk perusahaan, biasanya melalui kepemilikan mayoritas saham perusahaan (Baker dkk. 2012:2).

\subsection{Total Aset}

Menurut Margaretha (2003:108), total aktiva adalah total atau jumlah keseluruhan dari kekayaan perusahaan yang terdiri dari aktiva tetap, aktiva lancar dan aktiva lain-lain, yang nilainya seimbang dengan total kewajiban dan ekuitas.

\subsection{Audit Delay}

Menurut Rachmawati (2008), Audit delay yang dimaksud dalam penelitian ini adalah perbedaan/senjang waktu audit, yaitu waktu yang dibutuhkan oleh auditor untuk menghasilkan laporan audit atas kinerja laporan keuangan suatu perusahaan. Senjang waktu audit ini diukur 
dari tanggal penutupan tahun buku, hingga tanggal diselesaikannya laporan audit independen yang tertera dalam laporan keuangan.

Menurut Angruningrum dan Wirakusuma (2013), audit delay merupakan keterlambatan penyelesaian audit yang dapat dihitung melalui selisih antara tanggal ditandatanganinya laporan auditor independen dengan tanggap tutup buku laporan keuangan tahunan. Sedangkan Menurut Ashton dkk. (1987), Badan Pengawasan Pasar Modal (Bapepam) mengharuskan perusahaan public untuk menyerahkan laporan keuangan tahunannya yang sudah disertai dengan opini auditor dan mengumumkannya kepada publik paling lambat akhir bulan ketiga (90 hari) setelah tanggal laporan keuangan. Proses audit sangat memerlukan waktu untuk mengumpulkan bukti-bukti yang cukup dan kompeten yang dapat mendukung opini auditor, hal ini adanya time lag yang nantinya akan sangat berpengaruh terhadap ketepatan waktu pelaporan keuangan perusahaan.

Dyer dan MC Hugh (1975) dalam Hilmi dan Ali (2008:4), ada 3 (tiga) kriteria keterlambatan untuk mengetahui rentang waktu pada penyampaian laporan keuangan, sebagai berikut:

1. Preliminary lag, yaitu rentang jumlah hari antara tanggal laporan keuangan sampai dengan penerimaan laporan akhir preliminary oleh bursa

2. Auditor's report lag, yaitu rentang jumlah hari antara tanggal laporan keuangan sampai tanggal laporan auditor ditandatangani

3. Total lag, yaitu rentang jumlah hari antara tanggal laporan keuangan sampai tanggal penerimaan laporan dipublikasikan oleh bursa.

Menurut Pradipta dan Suryono (2017), variabel audit delay diukur dengan menggunakan dummy variabel, berdasarkan tanggal pelaporan tahunan auditan ke Bapepam. Perusahaan yang dikategorikan tepat waktu jika laporan keuangan disampaikan selambatlambatnya pada tanggal 31 Maret, sedangkan perusahaan yang terlambat adalah perusahaan yang menyampaikan laporan keuangan setelah tanggal 31 Maret. Variabel ini diukur denganmenggunakan variabel dummy, dimana kategori 1 perusahaan yang tepat waktu dan kategori 0 untuk perusahaan yang tidak tepat waktu.

\section{Gambar 1. Model Penelitian}

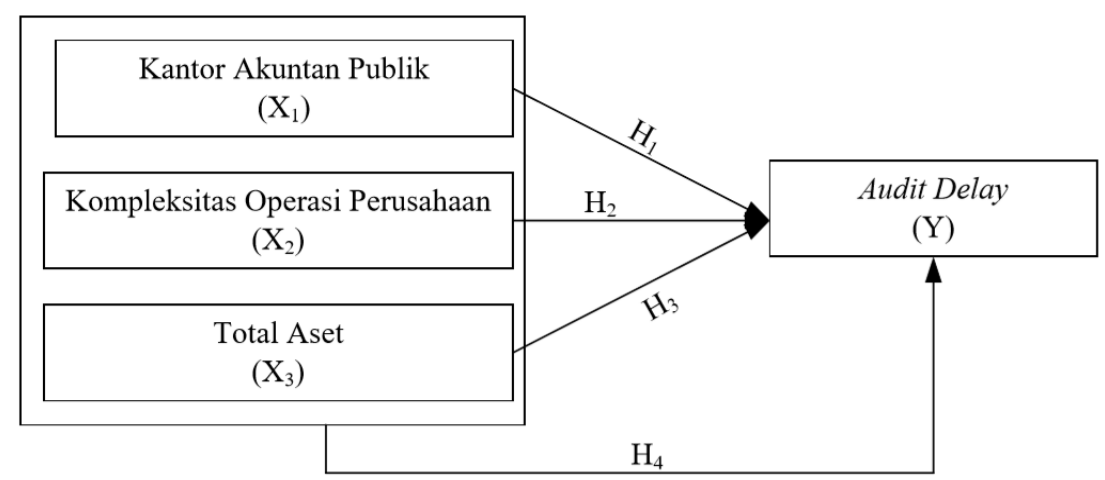




\subsection{Pengembangan Hipotesis}

\subsubsection{Kualitas Audit terhadap Audit delay}

Prabandari dan Rustiana (2007) menyatakan bahwa kantor akuntan publik internasional atau yang lebih dikenal dengan The Big Four membutuhkan waktu yang lebih singkat dalam menyelesaikan audit, karena KAP tersebut dianggap dapat melaksanakan auditsecara lebih efisien dan memiliki tingkat fleksibilitas jadwal waktu yang lebih tinggi untuk menyelesaikan audit tepat pada waktunya. Selain itu, KAP besar memperoleh insentif yang lebih tinggi untuk menyelesaikan pekerjaan auditnya lebih cepat dibandingkan dengan KAP lainnya. Waktu audit yang lebih cepat juga merupakan cara KAP besar untuk mempertahankan reputasinya.

Iskandar dan Trisnawati (2010), hasil audit delay pada perusahaan yang diaudit oleh KAP Big Four akan lebih cepat periode auditnya daripada perusahaan yang diaudit oleh KAP Non Big Four. Hal tersebut dikarenakan KAP yang tergolong Big Four mempunyai jumlah karyawan yang besar dan dapat mengaudit laporan keuangan lebih efektif dan efisien, serta memiliki jadwal yang fleksibel sehingga memungkinkan dalam menyelesaikan proses audit lebih cepat untuk menjaga reputasi dari KAP Big Four tersebut, sehingga diajukan hipotesis sebagai berikut.

H1. Kualitas Audit berpengaruh terhadap Audit delay

\subsubsection{Kompleksitas Operasi Perusahaan terhadap Audit delay}

Ahmad, et. al (2008), perusahaan yang memiliki kompleksitas operasi perusahaan yang tinggi maka auditor akan memerlukan waktu yang lebih lama dalam penyelesaian proses audit. Martius (2012:12) menyatakan ketergantungan yang semakin kompleks terjadi apabila organisasi dengan berbagai jenis atau jumlah pekerjaan dan unit menimbulkan masalah manajerial dan organisasi yang lebih rumit.

Ashton et.al (1987) dalam Owusu-Ansah (2000), dan Sulistyo (2010) menemukan bahwa terdapat hubungan positif antara kompleksitas operasi perusahaan dengan audit delay. Widyawati (2013) menyatakan bahwa perusahaan dengan jumlah anak perusahaan yang besar akan memiliki audit delay yang lebih panjang karena memiliki tingkat kompleksitas akuntansi dan audit yang lebih tinggi. Tingkat kompleksitas dari operasi perusahaan bergantung pada jumlah dan lokasi dari unit operasinya (cabang) dan diversifikasi produk dan pasar, diduga akan mempengaruhi lama waktu auditor untuk menyelesaikan auditnya yang pada akhirnya mempengaruhi lama waktu perusahaan mempublikasikan laporan keuangannya ke publik. Berdasarkan uraian tersebut, diajukan hipotesis sebagai berikut :

H2. Kompleksitas Operasi Perusahaan berpengaruh terhadap Audit delay 


\subsubsection{Total Aset Terhadap Audit delay}

Kartika (2009) menyatakan bahwa audit delay memiliki hubungan negatif dengan total aset, hal ini dikarenakan perusahaan yang memiliki total aset yang besar mempunyai sistem pengendalian internal yang baik sehingga dapat mengurangi tingkat kesalahan dalam penyajian laporan keuangan perusahaan dan memudahkan auditor dalam melakukan pengauditan laporan keuangan.

Hasil ini berbeda dengan yang ditemukan Kristanti (2014) yaitu total aset terkait dengan ukuran dari suatu perusahaan. Perusahaan yang memiliki total aset yang besar memiliki hubungan dengan ketepatan waktu laporan keuangan. Perusahaan yang memiliki total aset yang besar akan memerlukan waktu yang lebih panjang dalam audit delay. Dikarenakan semakin besar ukuran suatu perusahaan, maka semakin banyak juga informasi yang terkandung di dalam perusahaan tersebut. Informasi yang banyak tersebut akan mengakibatkan semakin luasnya pada lingkup auditnya, sehingga waktu yang dibutuhkan auditor untuk penyelesaian audit laporan keuangan tahunan atau audit delay lebih lama.

Ariyanti (2017), semakin besar nilai aktiva perusahaan maka semakin pendek audit delaynya dan sebaliknya, jika semakin kecil nilai aktiva perusahaan makan semakin lama audit delaynya. Perusahaan yang memiliki jumlah aset yang lebih besar cenderung akan menyelesaikan auditnya lebih lama dibandingkan dengan perusahaan yang memiliki jumlah aset yang lebih kecil, peristiwa ini dikarenakan semakin besar ukuran perusahaan maka semakin banyak prosedur audit yang harus ditempuh. Berdasarkan uraian tersebut, diajukan hipotesis sebagai berikut :

H3. Total Aset berpengaruh Terhadap Audit delay

\section{Metodologi Penelitian}

\subsection{Pengukuran dan Definisi Operasional}

Dalam penelitian ini yang berperan sebagai variabel dependen adalah Audit Delay. Rachmawati (2008) menyatakan audit delay adalah rentang waktu penyelesaian audit laporan keuangan tahunan yang diukur berdasarkan lamanya hari yang dibutuhkan untuk memperoleh laporan auditor independen atas audit laporan keuangan tahunan perusahaan, sejak tanggal tahun tutup buku perusahaan yaitu 31 Desember sampai tanggal tertera pada laporan auditor independen. Selisih jarak waktu antara berakhirnya tahun fiskal dengan tanggal diterbitkannya laporan audit inilah yang disebut dengan audit delay. Audit delay diukur dengan menghitung jumlah hari dari tanggal tutup tahun buku perusahaan sampai tanggal yang tertera pada laporan auditor independen. 
Selanjutnya terdapat tiga variabel independen pada penelitian ini, di antaranya adalah: (1) Kantor Akuntan Publik: Menurut SK. Menkeu No. 43/KMK.017/1997 tertanggal 27Januari 1997 sebagaimana diubah dengan SK. Menkeu No. 470/KMK.017/1999 tertanggal 4 Oktober 1999, Kantor Akuntan Publik adalah lembaga yang memiliki izin dari Menteri Keuangan sebagai wadah bagi akuntan publik dalam menjalankan pekerjaannya; (2) Kompleksitas Operasi Perusahaan: Menurut Martinus (2012), kompleksitas organisasi atau operasi merupakan akibat dari pembentukan departemen dan pembagian pekerjaan yang memiliki fokus terhadap jumlah unit yang berbeda. Ketergantungan yang semakin kompleks terjadi apabila organisasi dengan berbagai jenis atau jumlah pekerjaan menimbulkan masalah manajerial dan organisasi yang lebih rumit; (3) Total Aset: Menurut Haryono (2011), aset adalah sumber-sumber ekonomi yang dimiliki perusahaan yang biasa dinyatakan dalam satuan uang.

\subsection{Metode Analisis Data}

Jenis penelitian ini menggunakan pendekatan kuantitatif, bertujuan untuk meneliti populasi atau sampel tertentu. Data yang dipakai pada penelitian ini adalah data sekunder berupa laporan keuangan (financial report) pada industri dasar dan kimia yang terdaftar di BEI periode 2012-2016 yang berjumlah 65 perusahaan. Populasi penelitian ini merupakan seluruh perusahaan Industri dasar dan kimia yang terdaftar di BEI periode 2012-2016. Pengambilan sampel dengan menggunakan purposive sampling dengan kriteria sebagai berikut: (1) Industri Dasar dan Kimia yang terdaftar di BEI periode 2012-2016; (2) Industri Dasar dan Kimia yang mempublikasikan laporan keuangan secara berturut-turut pada periode $2012-2016$. Sampel pada penelitian ini diperoleh dari perhitungan purposive sampling pada industri dasar dan kimia yang terdaftar di BEI periode 2012-2016 sebagai berikut:

\section{Tabel 1. Purposive Sampling}

\begin{tabular}{|c|l|c|}
\hline \multicolumn{1}{|l|}{ No } & \multicolumn{1}{|c|}{ Kriteria } & Jumlah \\
\hline 1. & Perusahaan industri dasar dan kimia yang terdaftar di BEl periode 2012 - 2016. & 65 \\
\hline 2. & $\begin{array}{l}\text { Perusahaan industri dasar dan kimia yang tidak menyajikan laporan keuangan } \\
\text { yang lengkap pada periode 2012 - 2016. }\end{array}$ & $(18)$ \\
\hline 3. & $\begin{array}{l}\text { Perusahaan industri dasar dan kimia yang tidak memiliki laba positif pada periode } \\
2012-2016 .\end{array}$ & $(25)$ \\
\hline \multicolumn{2}{|c|}{ Total sampel } & $\mathbf{2 2}$ \\
\hline
\end{tabular}

Total jumlah data perusahaan yang dapat dijadikan sampel adalah 22 perusahaan, sedangkan data yang digunakan dalam penelitian ini adalah sebanyak 110 sampel yang diambil dari jumlah sampel 22 perusahaan dikalikan dengan 5 periode penelitian.

Pada penelitian ini, peneliti akan menggunakan metode analisis regresi logistik untuk mengetahui ada atau tidaknya pengaruh antara variabel independen (kantor akuntan publik , kompleksitas operasi perusahaan dan total aset terhadap variabel dependen (Audit delay). 
Pemilihan metode analisis tersebut karena variabel dependen penelitian ini merupakan variabel yang memiliki data kategorikal atau regresi dengan variabel dependen berupa angka biner yaitu nilai 1 (mengalami Audit delay) atau 0 (tidak mengalami Audit delay). Persamaan model logistic regression yang digunakan dalam penelitian ini adalah sebagai berikut:

$$
\operatorname{Ln} \frac{\mathrm{AD}}{1-\mathrm{AD}}=\mathrm{X}_{0}+\mathrm{b}_{1} \mathrm{X}_{1}+\mathrm{b}_{2} \mathrm{X}_{2}+\mathrm{b}_{3} \mathrm{X}_{3}+\mathrm{e}
$$

Keterangan:

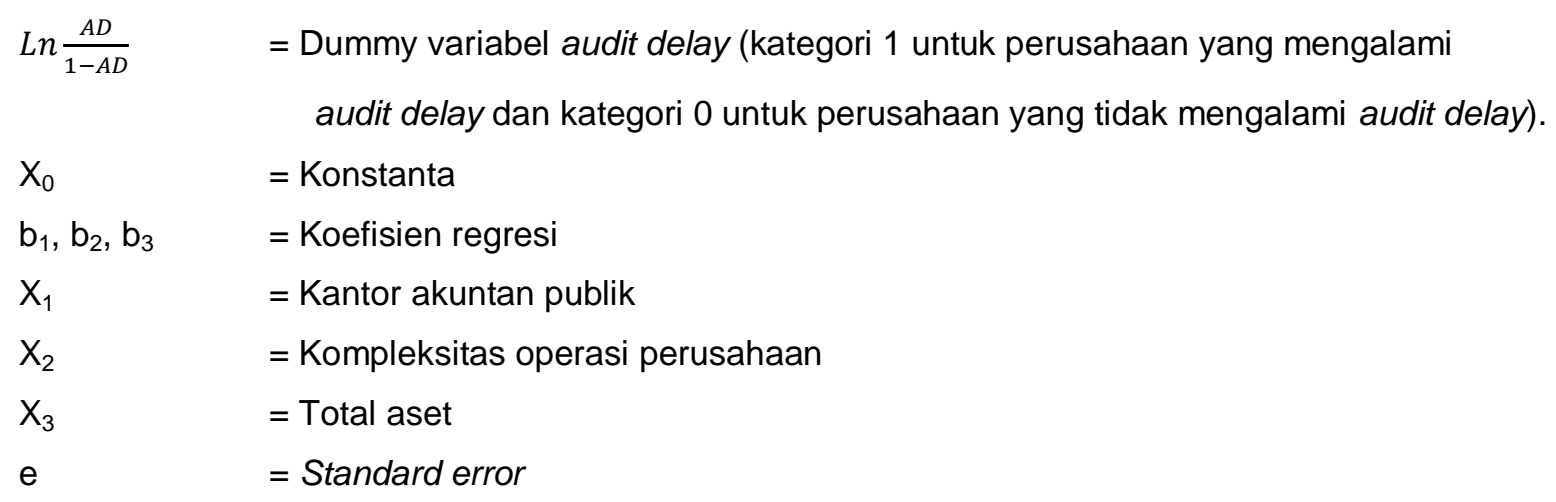

\section{Analisis dan Pembahasan}

\subsection{Statistik Deskriptif}

Jumlah data $(\mathrm{N})$ yang digunakan dalam penelitian ini sebanyak 65 dari 22 laporan keuangan publikasi tahunan industri dasar dan kimia yang terdaftar di BEI pada periode 2012 2016. Dari data statistik deskriptif didapatkan bahwa:

a. Nilai minimum KAP adalah 0 yang menunjukkan jumlah perusahaan yang menggunakan KAP non Big Four. Nilai maksimum KAP adalah 1 yang menggunakan KAP Big Four. Nilai rata-rata KAP industri dasar dan kimia yang terdaftar di BEl pada periode 2012 - 2016 adalah 0.41 dengan standar deviasi sebesar 0.494 .

b. Nilai minimum kompleksitas operasi perusahaan adalah 0 yang menunjukkan tidak memiliki anak perusahaan. Nilai maksimum kompleksitas operasi perusahaan adalah 1 yang menunjukkan memiliki anak perusahaan. Nilai rata-rata kompleksitas operasi industri dasar dan kimia yang terdaftar di BEI pada periode 2012 - 2016 adalah 0.73 dengan standar deviasi sebesar 0.447 .

c. Nilai minimum total aset adalah sebesar Rp. 22.755.160.000 yang terdapat pada PT. Indopoly Swakarsa Industry,Tbk tahun 2012. Nilai maksimum total aset adalah sebesar Rp. 44.226.895.982.000 yang terdapat pada PT. Semen Gresik, Tbk tahun 2016. Nilai rata-rata total aset industri dasar dan kimia yang terdaftar di BEI pada periode 2012 - 2016 adalah 5.393.235.118.000 dengan standar deviasi sebesar 9.209.505.202.000.000. 
d. Nilai minimum audit delay adalah 0 yang menunjukkan perusahaan yang tidak tepat waktu pelaporan. Nilai maksimum audit delay adalah 1 yang menunjukkan perusahaan yang melakukan pelaporan tepat waktu. Nilai rata-rata audit delay pada industri dasar dan kimia yang terdaftar di BEI pada periode 2012 - 2016 adalah 0.99 dengan standar deviasi sebesar 0.095 .

e. Sampel pada penelitian ini terdiri dari 65 perusahaan dengan 5 tahun periode penelitian sehingga diperoleh 110 data observasi. Dari keseluruhan observasi sebanyak 1 data mengalami tidak mengalami audit delay dan 109 data mengalami audit delay.

\subsection{Uji Model Fit (Overall Model Fit Test)}

Tabel 2: Nilai -2 log likelihood (-2 LL Awal)

\begin{tabular}{|l|l|l|l|}
\multicolumn{2}{c}{ Iteration } & -2 Log likelihood & Coefficients Constants \\
\hline Step 0 & 1 & 32.820 & 1.964 \\
\hline & 2 & 16.525 & 3.020 \\
\hline & 3 & 12.297 & 3.864 \\
\hline & 4 & 11.464 & 4.433 \\
\hline & 5 & 11.393 & 4.661 \\
\hline & 6 & 11.392 & 4.691 \\
\hline & 7 & 11.392 & 4.691 \\
\hline
\end{tabular}

Tabel 3: Nilai-2 log likelihood (-2 LL Awal)

\begin{tabular}{|r|r|r|r|r|r|r|}
\multicolumn{2}{c}{ Iteration } & $\begin{array}{c}-2 \text { Log } \\
\text { likelihood }\end{array}$ & \multicolumn{1}{c|}{ Constants } & \multicolumn{2}{c|}{ KAP } & \multicolumn{2}{c|}{$\begin{array}{c}\text { Kompleksitas } \\
\text { Operasional } \\
\text { Perusahaan }\end{array}$} & Total Aset \\
\hline Step 1 & 1 & 32.646 & 2.036 & -.129 & -.068 & .000 \\
\hline & 2 & 15.974 & 3.251 & -.391 & -.211 & .000 \\
\hline & 3 & 10.998 & 4.492 & -.957 & -1.162 & .000 \\
\hline & 4 & 9.196 & 5.923 & -1.869 & -1.970 & .000 \\
\hline & 5 & 8.448 & 7.563 & -2.892 & -2.847 & .000 \\
\hline & 6 & 8.154 & 9.335 & -3.901 & -3.777 & .000 \\
\hline & 7 & 8.047 & 11.212 & -4.905 & -4.749 & .000 \\
\hline & 8 & 8.008 & 13.164 & -5.901 & -5.740 & .000 \\
\hline & 9 & 7.994 & 15.150 & -6.897 & -6.737 & .000 \\
\hline & 10 & 7.989 & 17.145 & -7.895 & -7.735 & .000 \\
\hline & 11 & 7.987 & 19.143 & -8.894 & -8.735 & .000 \\
\hline & 12 & 7.986 & 21.142 & -9.894 & -9.735 & .000 \\
\hline & 13 & 7.986 & 23.142 & -10.894 & -10.735 & .000 \\
\hline & 14 & 7.986 & 25.142 & -11.894 & -11.735 & .000 \\
\hline & 15 & 7.986 & 27.142 & -12.894 & -12.735 & .000 \\
\hline & 16 & 7.986 & 29.142 & -13.894 & -13.735 & .000 \\
\hline & 17 & 7.986 & 31.142 & -14.894 & -14.735 & .000 \\
\hline & 18 & 7.986 & 33.142 & -15.894 & -15.735 & .000 \\
\hline & 19 & 7.986 & 35.142 & -16.894 & -16.735 & .000 \\
\hline & 20 & 7.986 & 37.142 & -17.894 & & \\
\hline
\end{tabular}

Uji regresi logistik yang pertama dilakukan dalam penelitian ini adalah menguji apakah model regresi yang dibuat adalah model fit dengan data penelitian. Pengujian ini dilakukan 
dengan melihat nilai -2 LL awal dengan -2 LL akhir pada tabel iteration history pada hasil penelitian.

Dari tabel 2 di atas dapat dilihat bahwa nilai -2 log likelihood awal (-2 LL awal) pada block number $=0$, yaitu yang hanya memasukkan konstanta saja adalah 11.392 dan pada tabel 3 di bawah dapat dilihat bahwa nilai -2 log likelihood akhir (-2LL akhir) pada block number = 1 yang memasukkan konstanta dan seluruh variabel independen adalah sebesar 7.986. Adanya pengurangan nilai antara -2LL awal dengan -2LL akhir menunjukkan bahwa model fit dengan data. Menurut Ghozali (2013), penurunan nilai -2 log likelihood menunjukkan bahwa model penelitian ini dinyatakan model fit. Artinya, Penurunan likelihood ini menunjukkan mode regresi yang lebih baik atau dengan kata lain model yang dihipotesiskan model fit dengan data.

\subsection{Uji Kelayakan Model}

Untuk menilai kelayakan model regresi yang digunakan dapat dilihat dari nilai Hosmer and Lemeshow test. Dari tabel uji Hosmer and Lemeshow test menunjukkan bahwa besarnya nilai chi-square 0,190 dan probabilitas signifikansi 0,986 yang nilai berada di atas 0,05 sehingga dapat disimpulkan bahwa model regresi logistik biner yang digunakan mampu memprediksi nilai observasinya.

\subsection{Pengujian Hipotesis}

Hasil pengujian hipotesis bertujuan untuk mengetahui pengaruh likuiditas dan opini audit ketepatan waktu dalam pelaporan keuangan pada industri dasar dan kimia yang terdaftar di BEI pada periode 2012 - 2016. Informasi awal untuk pengujian dengan regresi logistik.

\subsubsection{Uji Simultan - G}

Berdasarkan uji simultan - G, pengujian variabel pengaruh KAP, kompleksitas operasi perusahaan, total aset terhadap audit delay pada industri dasar dan kimia yang terdaftar di BEI pada periode 2012 - 2016 dengan menggunakan regresi logistik diperoleh nilai sebesar 0.333. Nilai signifikan tersebut jauh lebih besar dari tingkat signifikansi $(0,05)$, dengan demikian hipotesis ditolak. 


\subsubsection{Uji Parsial - Wald dan Uji Hipotesis Logistik}

Untuk menentukan hasil akhir dari penelitian dan menjawab hipotesis yang disusun sebelumnya, didapatkan hasil pengujian hipotesis regresi logistik pada tingkat signifikansi $5 \%$. Berikut adalah persamaannya.

$$
\begin{gathered}
\operatorname{Ln} \frac{\mathrm{AD}}{1-\mathrm{AD}}=\mathrm{X}_{0}+\mathrm{b}_{1} \mathrm{X}_{1}+\mathrm{b}_{2} \mathrm{X}_{2}+\mathrm{b}_{3} \mathrm{X}_{3}+\mathrm{e} \\
\operatorname{Ln} \frac{\mathrm{AD}}{1-\mathrm{AD}}=37.142-17.894 \mathrm{KAP}-16.735 \mathrm{KOP}+0.00 \text { Total Aset }
\end{gathered}
$$

Interpretasi dari persamaan regresi logistik di atas adalah sebagai berikut :

1. Dengan nilai intersep yang sebesar 37.142 berarti probabilitas perusahaan untuk melakukan audit delay sudah tepat.

2. Variabel independen pertama yaitu KAP menunjukkan nilai koefisien negatif sebesar 17.894 dengan probabilitas variabel sebesar 0.997 di atas nilai signifikansi 0,05 artinya dapat disimpulkan bahwa HO diterima. Artinya tidak terdapat pengaruh KAP tidak mempengaruhi terjadinya audit delay pada industri dasar dan kimia yang terdaftar di BEI pada periode 2012 - 2016. Nilai eksponen KAP sebesar 0.00 menunjukan bahwa tidak ada pengaruh KAP terhadap audit delay.

3. Variabel independen kedua yaitu kompleksitas operasi perusahaan menunjukkan nilai koefisien negatif sebesar - 16.735 dengan probabilitas variabel sebesar 0.998 di atas nilai signifikansi 0,05 dan dapat disimpulkan bahwa $\mathrm{HO}$ diterima. Artinya tidak terdapat pengaruh kompleksitas operasi perusahaan terhadap audit delay pada industri dasar dan kimia yang terdaftar di BEI pada periode 2012 - 2016. Nilai eksponen kompleksitas operasi perusahaan sebesar 0.00 menunjukan bahwa tidak ada pengaruh kompleksitas operasi perusahaan terhadap audit delay.

4. Variabel independen ketiga yaitu total aset sebesar 0.00 dengan probabilitas variabel sebesar 0.618 di atas nilai signifikansi 0,05 dan dapat disimpulkan bahwa $\mathrm{HO}$ diterima. Artinya tidak ada pengaruh total aset terhadap audit delay pada industri dasar dan kimia yang terdaftar di BEI pada periode 2012 - 2016. Nilai eksponen total aset sebesar 1.000 menunjukan bahwa peluang pengaruh total aset terhadap audit delay sebesar 1 kali dibandingkan dengan tidak melakukan audit delay.

\subsubsection{Uji Koefisien Determinasi (Nagelkerke $R$ Square)}

Nilai Nagelkerke $R$ Square bervariasi antara 1 (satu) dan 0 (nol). Semakin mendekati nilai 1 maka model dianggap semakin goodness of fit sementara semakin mendekati 0 maka model semakin tidak goodness of fit. Berdasarkan hasil pengujian, didapatkan bahwa nilai nagelkerke 
$R$ Square pada penelitian ini sebesar 0.310 yang dapat menyatakan bahwa variabilitas variabel dependen yang dapat dijelaskan oleh variabilitas variabel independen sebesar $31 \%$, sedangkan sisanya sebesar $69 \%$ dapat dijelaskan oleh faktor-faktor lain yang tidak disertakan dalam penelitian ini.

\subsection{Diskusi}

\subsubsection{Pengaruh KAP terhadap Audit delay}

Hasil penelitian menunjukkan bahwa KAP tidak berpengaruh terhadap audit delay pada industri dasar dan kimia yang terdaftar di BEI pada periode $2012-2016$. Hasil penelitian ini tidak sesuai dengan Prabandari dan Rustiana (2007) menyatakan bahwa kantor akuntan publik internasional atau yang lebih dikenal dengan The Big Four membutuhkan waktu yang lebih singkat dalam menyelesaikan audit, karena KAP tersebut dianggap dapat melaksanakan audit secara lebih efisien dan memiliki tingkat leksibilitas jadwal waktu yang lebih tinggi untuk menyelesaikan audit tepat pada waktunya.

KAP tidak berpengaruh terhadap audit delay, hal ini karena di Indonesia belum ada lembaga yang menilai kinerja dari kantor akuntan publik, sehingga belum dapat menjelaskan kinerja apakah KAP yang masuk The Big Four memiliki kinerja yang lebih baik atau tidak. Selain itu audit delay lebih ditentukan oleh kondisi cara-cara penyajian laporan keuangan masingmasing perusahaan.

\subsubsection{Pengaruh kompleksitas operasi perusahaan terhadap audit delay}

Hasil penelitian menunjukkan bahwa kompleksitas operasi perusahaan tidak berpengaruh terhadap audit delay pada industri dasar dan kimia yang terdaftar di BEI pada periode 2012 - 2016. Hasil penelitian ini tidak sesuai dengan Ashton et.al (1987) dalam OwusuAnsah (2000), dan Sulistyo (2010) yang menemukan bahwa terdapat hubungan positif antara kompleksitas operasi perusahaan dengan audit delay.

Hasil penelitian ini sejalan dengan Ahmad, et. al (2008), perusahaan yang memiliki kompleksitas operasi perusahaan yang tinggi maka auditor akan memerlukan waktu yang lebih lama dalam penyelesaian proses audit.

\subsubsection{Pengaruh total aset terhadap audit delay}

Hasil penelitian menunjukkan bahwa total aset tidak berpengaruh terhadap audit delay pada industri dasar dan kimia yang terdaftar di BEI pada periode 2012 - 2016. Hasil penelitian 
ini tidak sejalan dengan Kartika (2009) bahwa audit delay memiliki hubungan negatif dengan total aset, hal ini dikarenakan perusahaan yang memiliki total aset yang besar mempunyai sistem pengendalian internal yang baik sehingga dapat mengurangi tingkat kesalahan dalam penyajian laporan keuangan perusahaan dan memudahkan auditor dalam melakukan pengauditan laporan keuangan.

Hasil penelitian ini sejalan dengan hasil penelitian Ariyanti (2017), semakin besar nilai aktiva perusahaan maka semakin pendek audit delaynya dan sebaliknya, jika semakin kecil nilai aktiva perusahaan makan semakin lama audit delaynya. Perusahaan yang memiliki jumlah aset yang lebih besar cenderung akan menyelesaikan auditnya lebih lama dibandingkan dengan perusahaan yang memiliki jumlah aset yang lebih kecil, peristiwa ini dikarenakan semakin besar ukuran perusahaan maka semakin banyak prosedur audit yang harus ditempuh.

\section{Kesimpulan, Keterbatasan, dan Saran}

\subsection{Kesimpulan}

KAP, kompleksitas operasi perusahaan dan total aset secara parsial tidak berpengaruh signifikan terhadap audit delay. Dengan meningkatnya atau menurunnya KAP, kompleksitas operasi perusahaan dan total aset tidak mempengaruhi terjadinya audit delay pada industri dasar dan kimia yang terdaftar di BEI pada periode 2012 - 2016.

Pengujian variabel pengaruh KAP, kompleksitas operasi perusahaan dan total aset terhadap audit delay pada industri dasar dan kimia yang terdaftar di BEI pada periode 2012 2016.dengan menggunakan nilai nagelkerke $R$ Square pada penelitian ini sebesar 0.310 yang dapat menyatakan bahwa variabilitas variabel dependen yang dapat dijelaskan oleh variabilitas variabel independen sebesar $31 \%$, sedangkan sisanya sebesar $69 \%$ dapat dijelaskan oleh faktor-faktor lain yang tidak disertakan dalam penelitian ini.

Hasil penelitian ini bagi peneliti sendiri untuk menambah pengetahuan dan wawasan tentang pengaruh KAP, kompleksitas operasi perusahaan, total aset terhadap audit delay, dan dapat dijadikan perbandingan dengan teori yang didapat dari bangku kuliah dengan praktik yang terjadi di lapangan.

Hasil penelitian ini sangat bermanfaat bagi para pengambil keputusan pada perusahaan jenis industri yang dijadikan subjek pada penelitian ini, bahwa penting untuk memperhatikan kinerja keuangannya agar hal tersebut tidak mempengaruhi audit delay karena kinerja keuangan yang kurang baik akan mempengaruhi opini audit dalam memberikan pendapatnya terhadap laporan keuangan perusahaan 


\subsection{Keterbatasan dan Saran}

Dalam penelitian ini terdapat beberapa keterbatasan yang kemungkinan dapat mempengaruhi hasil penelitian, antara lain variabel yang digunakan untuk mendeteksi audit delay pada penelitian ini hanya sebatas variabel yang dikembangkan dari KAP, kompleksitas operasi perusahaan dan total aset, disarankan untuk menambahkan variabel yang lainnya untuk dapat mendeteksi terjadinya audit delay serta studi selanjutnya dapat dilakukan dengan memperluas sampel.

\section{Daftar Pustaka}

Ahmad, Raja Adzrin Raja dan Khairul Anuar Kamarudin, 2003. Audit delay and The Timeliness of Corporate Reporting: Malaysian Evidence. MARA University of Technology: Malaysia.

Eka A.S., Kristanti. 2014. Pengaruh Total Aset, ROA, DER, Ukuran KAP dan Laba atau Rugi Perusahaan Terhadap Audit Delay Pada Perusahaan Manufaktur yang Terdaftar di Bursa Efek Indonesia Periode 2011 - 2012. $3^{\text {rd }}$ Economic and Business Research Festival. Fakultas Ekonomi, Universitas Wijaya Kusuma Surabaya

Kartika, A. 2009. Faktor-Faktor Yang Mempengaruhi Audit Delay Di Indonesia: Studi Empiris Pada Perusahaan-Perusahaan LQ 45 Yang Terdaftar Di Bursa Efek Indonesia. Jurnal Bisnis dan Ekonomi. Vol. $16: 1-17$

Martius. 2012. Analisis Praktik Akuntansi Manajemen Pada Perusahaan Manufaktur (Studi Empiris di Kawasan Industri Batam). Artikel. Program Magister Sains Akuntansi Pasca Sarjana Universitas Andalas. Padang.

Margaretha, Farah. 2004. Teori Dan Aplikasi Manajemen Keuangan Investasi dan Sumber Dana Jangka Pendek. PT. Grasindo. Jakarta.

Ng, P. P. H. dan B. Y. K.Tai. 1994. An empirical examination of the determinants of audit delay in Hong Kong. British Accounting Review 26 (1): 43-59.

Owusu-Ansah, Stephen. 2000. Timeliness of Corporate Financial Reporting in Emerging Capital Market: Empirical Evidence from The Zimbabwe Stock Exchange. Journal Accounting and Business Research. Vol.30. No.3.

Pernyataan Standar Akuntansi Keuangan No. 1 (Revisi 2009) Penyajian Laporan Keuangan. Dewan Standar Akuntansi Keuangan-Ikatan Akuntansi Indonesia, Jakarta.

Rachmawati, Sistya. 2008. Pengaruh Faktor Internal dan Eksternal Perusahaan Terhadap Audit Delay dan Timeliness, Jurnal Akuntansi Keuangan, Vol. 10, No. 1.

Rizky, Ariyanti. 2017. Faktor-Faktor Yang Berpengaruh Terhadap Audit Delay Pada Perusahaan Liquid 45. Jurnal IImu dan Riset Akuntansi. Vol.6. No.8. Sekolah Tinggi Ilmu Ekonomi Indonesia (STIESIA), Surabaya.

Widyawati, Asri Adika dan Viska Anggraita 2013. Pengaruh Konvergensi, Kompleksitas Akuntansi, dan Probabilitas Kebangkrutan Terhadap Timeliness dan Manajemen Laba. $J A A I$. Vol. 17. No.2. Fakultas Ekonomi Universitas Indonesia. 